\title{
Influence of subcutaneous fat thickness on the carcass characteristics and meat quality of beef cattle
}

\author{
Bruna Boito $^{1^{*}}$ Fernando Kuss $^{2}$ Luis Fernando Glasenapp de Menezes ${ }^{2}$ \\ Eduardo Lisbinski ${ }^{1}$ Micheli de Paris ${ }^{1}$ Jacson Rodrigo Cullmann²
}

${ }^{1}$ Programa de Pós-graduação em Zootecnia, Departamento de Zootecnia, Universidade Federal do Rio Grande do Sul (UFRGS), Campus Agronômia, Av. Bento Gonçalves, 7712, 91540-000, Porto Alegre, RS, Brasil. E-mail: bruna.boito@hotmail.com. "Corresponding author. ${ }^{2}$ Programa de Pós-graduação em Zootecnia, Departamento de Zootecnia, Universidade Tecnológica Federal do Paraná (UTFPR), Campus Dois Vizinhos, PR, Brasil.

\begin{abstract}
The objective of this research was to examine the effect of subcutaneous fat thickness (SFT) on carcass characteristics and meat quality in 24-month-old British and crossbred British steers finished in feedlot systems. It was assessed using meta-analysis performed on data that was extracted from 46 published studies and comprising a total of 2,695 experimental units. We found that SFT was influenced by and increased linearly with hot carcass weights $(\mathrm{HCWs})$ and cold carcass weights $\left(C C W_{s}\right)$ and their yields; moreover, the bone fraction decreased whereas the muscle and fat fractions increased with higher levels of SFT. No significant differences were detected in meat quality variables. Thus, SFT appeared to have a direct influence on $\mathrm{HCW}, \mathrm{CCW}$, and the weight and yield of bone, muscle, and fat of castrated steers. A uniform fat thickness level of $6.0 \mathrm{~mm}$ SFT was determined to be the standard of quality of carcasses and meat products for consumers.

Key words: meta-analysis, adipose tissue, animal production, feedlot, meat quality.
\end{abstract}

Influência da espessura da gordura subcutânea nas características de carcaça e qualidade de carne de bovinos

RESUMO: O objetivo deste trabalho foi avaliar o efeito da espessura de gordura subcutanea (EGS) nas características de carcaça e qualidade de carne em novilhos, com até 24 meses de idade, britânicos ou suas cruzas terminados no sistema de confinamento. Para isso foi utilizado o sistema de meta-análise com dados extraidos de 46 artigos publicados, totalizando 2,695 unidades experimentais. Foi encontrado que a GS influencia no aumento linear no peso de carcaça quente (PCC) e fria (PCF) e em seus rendimentos. Além disso as frações de osso decaem enquanto as frações de músculo e gordura aumentam em altos níveis de GS. Não foi encontrada diferença significativa, mas variáveis de qualidade de carne. Assim a GS apresenta influência direta em PCC, PCF e nos pesos e rendimento de osso, músculo e gordura da carcaça de novilhos castrados. Um valor uniforme de gordura subcutânea de 6,00 mm é capaz de padronizar uma qualidade de carcaça e de produtos aos consumidores.

Palavras- chave: meta análise, tecido adiposo, produção animal, confinamento, qualidade de carne.

\section{INTRODUCTION}

Because of its large size and wide range of environmental conditions, beef production in Brazil varies greatly among different regions of the country. As such, the Brazilian cattle industry seeks alternative strategies for standardizing the quality of meat and carcass weights, which differ considerably among breeds and production systems. The use of feedlots represents an efficient strategy for maximizing beef production; however, in Brazil, most of the 209 million head of cattle raised in the country are grazed on pastures, with only about $11 \%$ finished in feedlots, WILKINSON (2010).

When assessing meat quality, consumers tend to focus on visual and organoleptic characteristics. According to SMITH et al. (2009) and GOMES et al. (2009), the greater the amount of energy that cattle consume, the higher the proportion of subcutaneous fat and consequently the more intramuscular fat there is in the meat, resulting in greater meat tenderness in the final product, an important factor for consumers. 
Bovine carcasses exhibit many differences (DONICHT et al. 2001). The lack of standardization for SFT levels in feedlot cattle often results in reductions in carcass and meat quality due to cooling, darkening, and shortening of muscle fibers, and higher fat content and excessive SFT can also reduce overall carcass yield (LAWRIE, 2005).

Numerous studies focusing on beef carcass and meat production have concluded that strategies for standardizing cattle production based on feedlot systems are needed. Research on factors such as slaughter weight (SW), carcass conformation, physiological maturity, and gender have provided abundant information about cattle performance characteristics; in contrast, data regarding losses due to the thawing and cooking of meat, meat $\mathrm{pH}$, marbling, color, and texture presented results that indicate the quality of the meat provided to consumers can be evaluated through analysis of SFT.

The objective of the present study was to examine the effect of SFT on carcass and meat quality characteristics in British or crossbred British castrated steers finished in a feedlot and slaughtered at 24 months of age.

\section{MATERIALS AND METHODS}

A systematic review of select papers from the scientific literature was performed in accordance with the procedures described in ROTHER (2007) from which data were collected concerning SFT (measured in millimeters following slaughter), as well as carcass characteristics and meat quality, of feedlotfinished British steers or British steer crossbreeds slaughtered at 24 months of age in commercial slaughterhouses following Brazilian regulations. The objective of this systematic review was to identify, select, and analyze the data provided by these studies. As such, only Brazilian studies involving steers 24 months of age that were finished in a feedlot were included in the meta-analysis. Thus, the search process, which was performed online, focused on sources like SCIELO, the Brazilian Journal of Animal Science, the Brazilian Association of Animal Science, Rural Science and Technology, universities with graduate programs relating to animal science, Coordenação de Aperfeiçoamento de Pessoal de Nível Superior (CAPES), the Brazilian Magazines of Veterinary Medicine and Animal Science, and Animal Science Journal Meetings. Following initial selection, the chosen papers were then re-evaluated for more specific criteria such as studies that provided detailed information about carcass characteristics and meat quality and that were published within the past 13 years. A total of 46 articles and 2,695 experimental units were included in the final analysis.

Additional information collected included the names of the author(s); the journal, volume, and date of publication; degree of British steer blood; animal category; gender; and number of animals, age at slaughter, sexual condition, and percentage of concentrate in the diet. Carcass properties included in the analysis included fat thickness; ageing time before and after pressure treatment; hot and cold carcass weight; relative proportions of bone, fat, and muscle; bone, fat and muscle weights; muscle:bone and muscle+fat:bone ratios; hindquarter, forequarter and side-cut weights; and relative proportions of the hindquarter, forequarter, and side-cut. For meat quality characteristics, color, texture, marbling, breaking cooling, cooking loss, shear, palatability, succulence, and conformation were included.

The selected articles were checked to determine if similar methodologies were used, after which the data was entered into an Excel spreadsheet and analyzed using SAS 2004 software, with SFT and slaughter weight set as co-variables to establish the animal's weight. These data were tested using a General Linear Models ANOVA, after which correlation and polynomial regression analyses were performed at $10 \%$ level of significance. The mathematical model proposed was:

$\mathrm{Y}_{\mathrm{ij}}=\mu+\mathrm{PA}_{\mathrm{k}}+\mathrm{T}_{\mathrm{i}}+\varepsilon_{\mathrm{ij}}$

where $Y_{i j}$ is the dependent variable; $\mu$ is the average of all observations; $P A_{k}$ represents the effect of SW; $T_{i}$ is the treatment effect; and $\varepsilon_{i j}$ represents the residual experimental error (error $b$ ).

For the polynomial regression, the following model was used, with $\mathrm{SW}$ as a covariate: $\mathrm{Y}_{\mathrm{ijk}}=\beta_{0}+\mathrm{PA}_{\mathrm{k}}+\beta_{1} \mathrm{X}_{\mathrm{i}}+\beta_{2} \mathrm{X}_{\mathrm{i}}^{2}+\alpha_{\mathrm{ijk}+} \varepsilon_{\mathrm{ijk}}$

where $Y_{i j k}$ represents the dependent variables; $\beta$ is the regression coefficient; $P A_{k}$ represents the effect of SW; $X_{i}$ represents the independent variables; $\alpha_{i j k}$ is the deviation of the regression; and $\varepsilon_{i j k}$ is the residual random error.

\section{RESULTS AND DISCUSSION}

The results indicated that hot carcass weights (HCWs) and cold carcass weights (CCWs) increased with fat thickness (Figure 1). According to BERG \& BUTTERFIELD (1976) relative proportions of specific tissues changes as the animal matures, typified by reductions in the grow rates of muscle and bone and increasing rates of fat deposit. DONICHT et al. (2011) reported that SFT had an inhibitory effect 


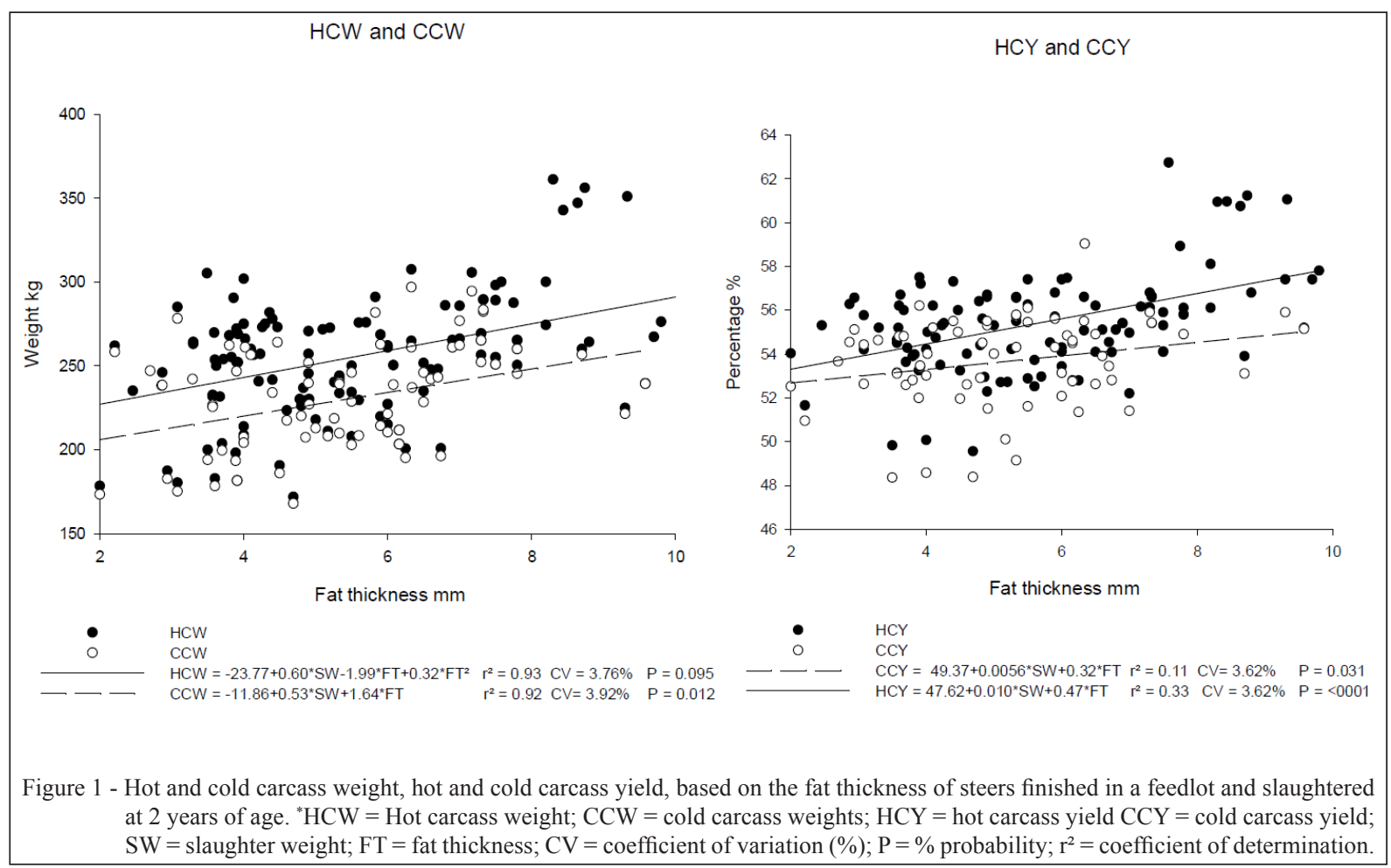

on cold carcass yield, in which lower amounts of SFT reduced muscle fiber shortening in the carcass, causing further fluid loss during cooling. The HCW is an important feature for cattle producers, because it is directly related to the animal's commercial value. Using an SFT of $6.0 \mathrm{~mm}$ in the formula in Figure 1 , a steer with a SW of $450 \mathrm{~kg}$ has approximately $269.69 \mathrm{~kg} \mathrm{HCW}$ and $249.98 \mathrm{~kg} \mathrm{CCW}$. In order to obtain optimal HCW and CCW levels in steers, the SFT should be $>4.5 \mathrm{~mm}$; to achieve such levels in Brazilian feedlots would require substantial increases in the amount of feed consumed by steers, which would increase productions costs for cattle producers (GESUALDI et al., 2006).

Slaughterhouses generally base their charge scales on HCW, and the SFT required by slaughterhouses ranges between $3-6 \mathrm{~mm}$ (GONZÁLEZ et al.,2012), levels that facilitate carcass handling, thereby reducing costs to the slaughterhouses. Using equations derived from Figure $1\left[\left(\mathrm{HCW}=-23.77+0.60^{*} \mathrm{SW}+1.99^{*} \mathrm{SF}\right.\right.$ $\left.+0.32^{*} \mathrm{SF}^{2}\right)$ and $\left(\mathrm{CCW}=-11.86+0.56^{*} \mathrm{SW}+1\right.$, $\left.64^{*} \mathrm{SF}\right)$ ], we compared the HCW and SFT values calculated in our study with those reported by PRADO et al. (2012) $(3.4 \mathrm{~mm}$ and $4.3 \mathrm{~mm}$ SFT); we estimated that the HCW of a steer with an SW of
$518 \mathrm{~kg}$ to be $\sim 297.49 \mathrm{~kg}$, with an SFT of $\sim 3.4 \mathrm{~mm}$ SFT; and $\sim 303.95 \mathrm{~kg}$, with an SFT of $\sim 4.8 \mathrm{~mm}$. These values were $\sim 8 \%$ higher than those presented in PRADO et al. (2012).

Once the energy demands for muscle deposition are complete, the animal begins to deposit excess energy as fat. By combining these factors, an improvement in animal performance can be achieved, thereby making the most of their productive potential (FERNANDES et al., 2008; MAGGIONI, 2009). With regard to the amount of fat tissue present in a bovine carcass, a study by NÜRNBERG et al. (1998) revealed that the fat deposition rate increased with the animal's age, and moreover, as the degree of physiological maturity increased, the proportion of adipose tissue tended to be larger, whereas the rate of muscle tissue deposition slowed. MAGGIONI (2009), however, noted that fat deposition can occur at all ages if dietary energy consumption is greater than that required by the animal.

The positive influence of SFT on absolute values for bone, fat, and muscle can be seen in figure 2 . Applying the equations for bone and muscle (expressed in $\mathrm{kg}$ ), peak SFT was determined to be $7.7 \mathrm{~mm}$, following which these variables gradually decline. The amount of fat $(\mathrm{kg})$ increased up to an SFT value of 8.5 $\mathrm{mm}$, beyond which SFT slightly decreased. 


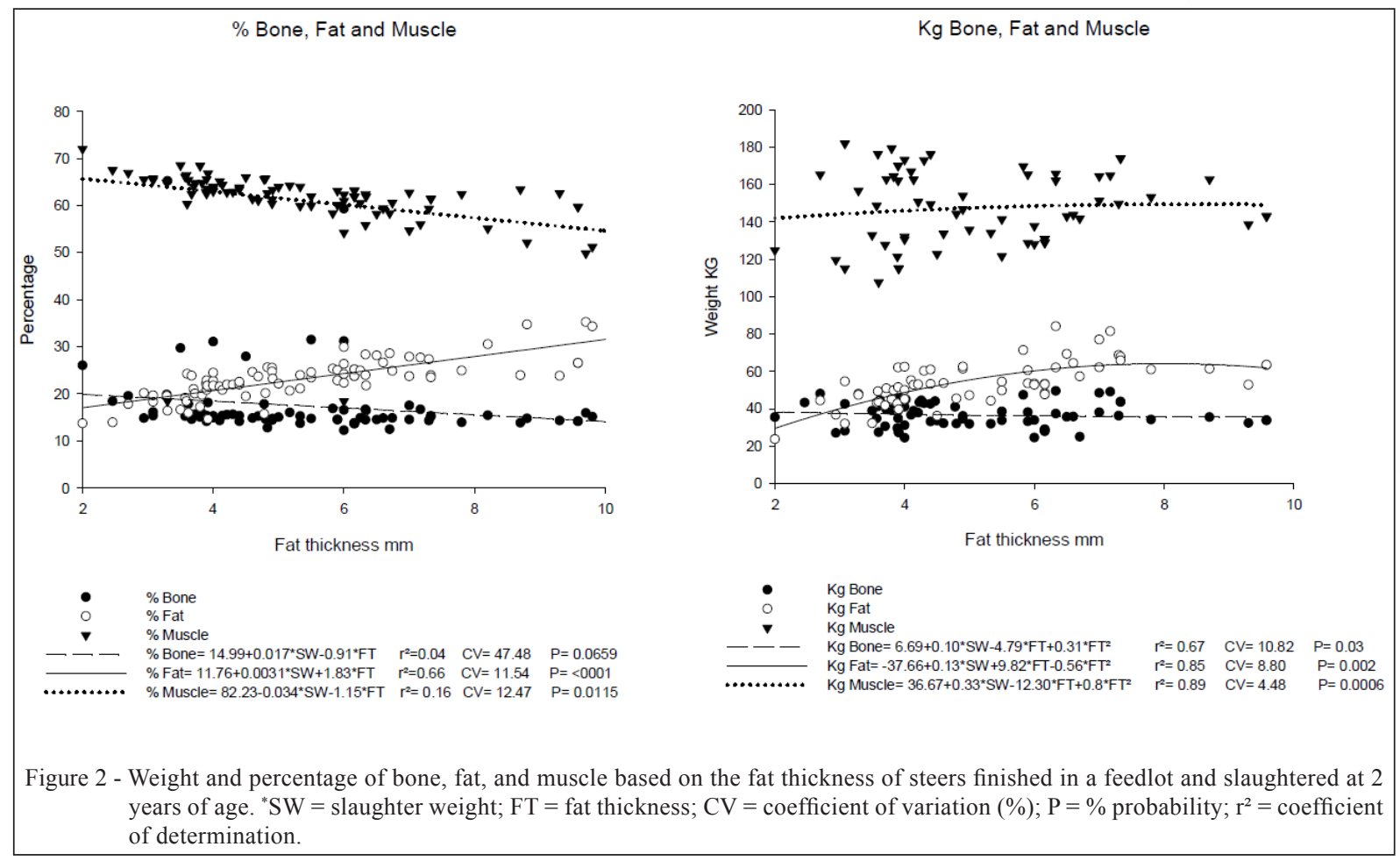

Carcass fat percentage increased linearly, and consequently, both bone and muscle percentages decreased in the steers (Figure 2). DONICHT et al. (2011) reported that steers finished in feedlots consisted of $63.5 \%$ muscle, $21.80 \%$ fat, and $14.9 \%$ bone when the SFT was $6 \mathrm{~mm}$. Using a variety of SFT values, PRADO et al. (2012) reported higher percentages of muscle and fat, and a smaller proportion of bone: the proportions of animals slaughtered with SFTs of $3.4 \mathrm{~mm}$ were $62.8 \%$ muscle, $21.4 \%$ fat, and $16.1 \%$ of bone, whereas those for animals slaughtered with an SFT of $4.8 \mathrm{~mm}$ were $64.5 \%$ muscle, $22.3 \%$ fat, and $14.2 \%$ bone. Plugging these values into the equations shown in figure 2, for animals with an SW of $450 \mathrm{~kg}$ and an SFT of $3.4 \mathrm{~mm}$, we obtained the proportions $62.74 \%$ muscle, $19.42 \%$ fat, and $19.78 \%$ bone. At an SFT of $4.8 \mathrm{~mm}$ and the same SW, we calculated the relative proportions to be $61.13 \%$ muscle, $21.98 \%$ fat, and $18.50 \%$ bone, values that correspond closely with the results of other recent studies.

The muscle:bone ratio increased linearly, corresponding to the enhanced carcass SFT (Figure 3). The edible portion of muscle:fat:bone was presented in quadratic form, with maximal levels observed at $8.8 \mathrm{~mm}$ SFT higher level of fat with excess SFT and can lead to excessive fat content, thereby reducing carcass yield (LAWRIE, 2005). Knowing the bone, muscle, and fat amount, permits the identification of the relationship between the most commercially important portions of the muscle:bone ratio in a carcass, as well as the ratio of the edible fraction of muscle:fat:bone. A greater amount of fat has a direct influence on the relationship between the edible and bone portions of a carcass.

The combination of high amount of muscle tissue, low proportions of bone, and optimal SFT levels are attractive to both beef producers and consumers, especially in regard to their occurrence in the prime cuts of the carcass, which are located in the hindquarters. This part of the animal is the most desirable to producers because cuts from these sections typically have the greatest commercial value (METZ et al., 2009; PINHEIRO et al., 2009).

According to LAWRIE (2005), only carcasses with a minimum SFT of $2.0-3.0 \mathrm{~mm}$ is considered good quality by the slaughterhouses, as this represents the lowest range of fat that provides protection for the carcass during the cooling process. Minimum levels of other carcass characteristics include proportions of $45-50 \%$ hindquarter, $38-43 \%$ forequarter, and $12-16 \%$ side-cut. Based on these values, and using a $2.0 \mathrm{~mm}$ SFT (Figure 4), our 


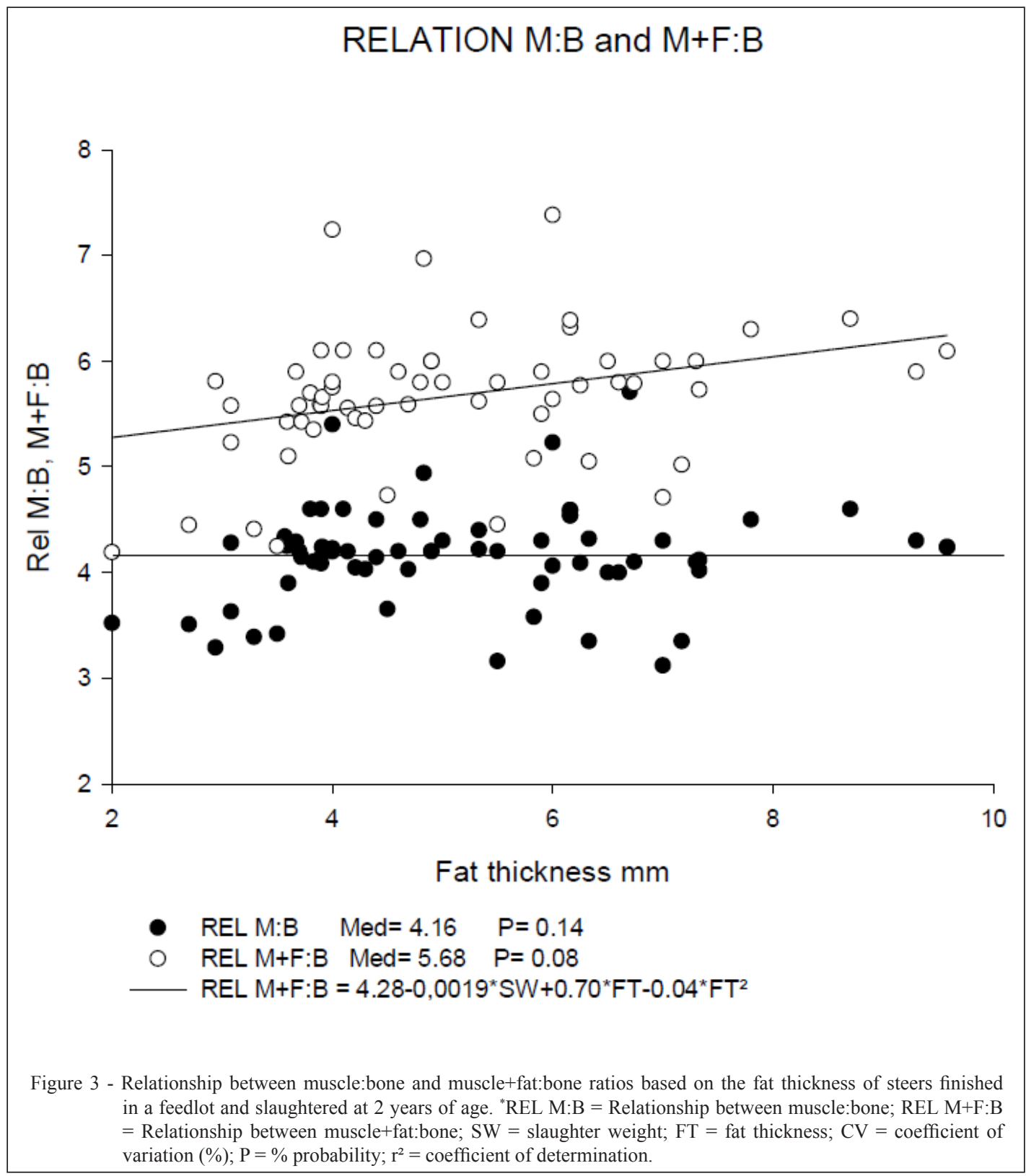

results corroborated those of Menezes et al. (2010), who proposed that commercial cuts could not be influenced by the SFT.

There were no significant differences between meat quality characteristics and the SFT of the animals (Table 1). According to FIORENTINI et al. (2012), consumers generally use visual cues when initially evaluating meat quality, particularly with regards to muscle color and fat content, followed by the degree of fluid loss during preparation, and finally, texture characteristics such as palatability, juiciness, and tenderness.

Among meat characteristics, tenderness and appearance are the components most often sought by consumers, with the degree of marbling a primary contributor to meat tenderness (CATTELLAM et al., 2009). Comparing the improvements in organoleptic characteristics with the final SFT, we found that there were no significant differences between these variables, suggesting that the SFT of feedlot-finished 


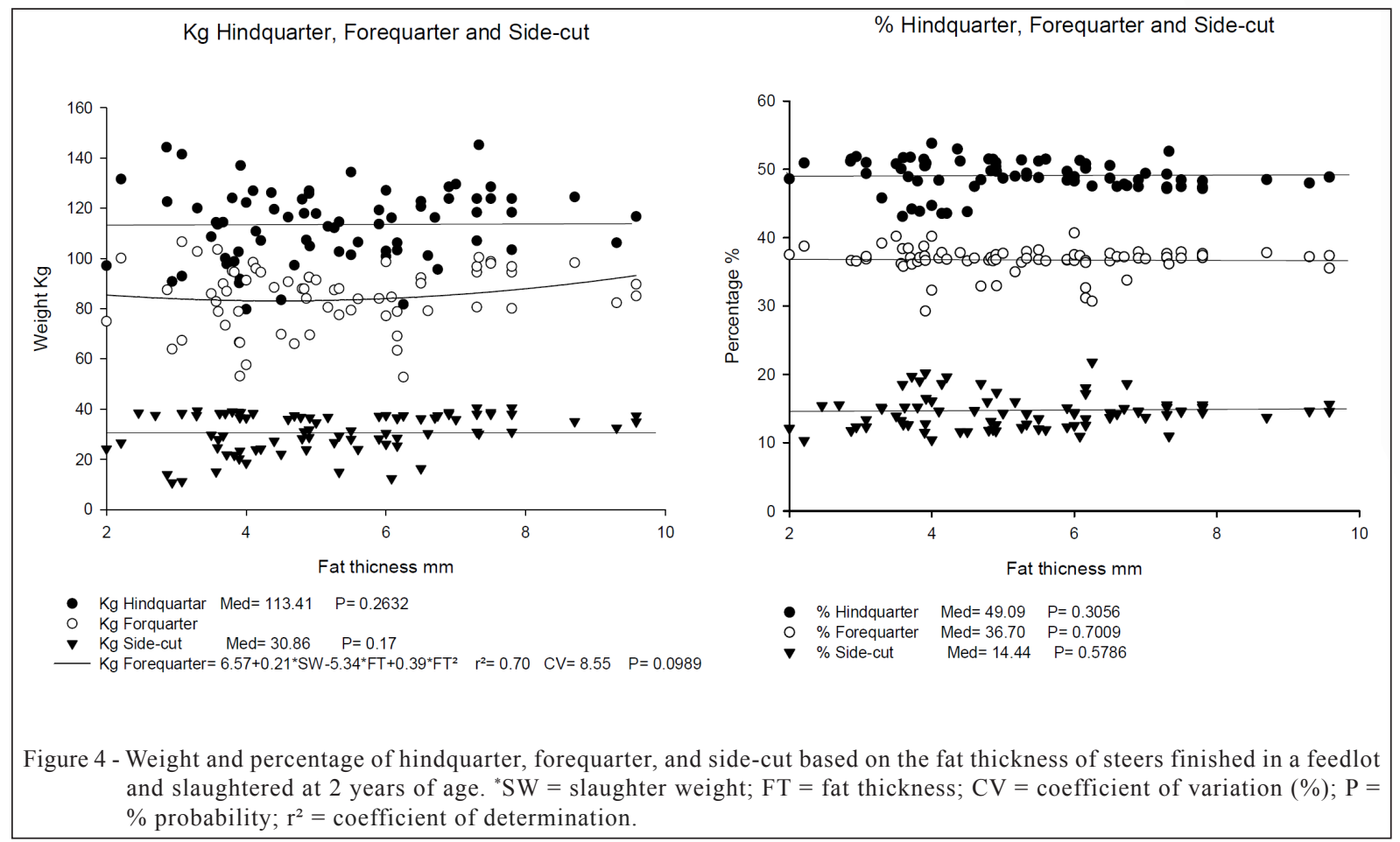

animals at the time of slaughter does not affect meat marbling, juiciness, or palatability.

Our results suggested that SFT had no effect on marbling $(\mathrm{P}=0.1847)$, juiciness $(\mathrm{P}=0.2233)$, or palatability $(\mathrm{P}=0.4296)$, which accords with the findings of ARBOITTE et al. (2011), who reported that young animals with SFTs $>4 \mathrm{~mm}$ displayed greater meat protection, which was directly related to lower fluid loss during cooling and cooking, thus resulting in greater meat juiciness and palatability according to Menezes et al. (2010). Animals with higher SFT were found to have correspondingly higher levels of marbling in their meat. According to ARBOITTE (2011), losses due to defrosting and

Table 1 - Qualitative characteristics.

\begin{tabular}{lccccc}
\hline Characteristics & $\mathrm{N}^{\circ}$ & Means & $\mathrm{R}^{2}$ & $\mathrm{CV}$ & $\mathrm{P}>\mathrm{F}$ \\
\hline Marbling, points $^{1}$ & 71 & 13.62 & 0.0023 & 218.71 & 0.6816 \\
Color, points $^{2}$ & 60 & 4.05 & 0.0294 & 12.50 & 0.1897 \\
Texture, points $^{2}$ & 68 & 4.32 & 0.0148 & 18.69 & 0.3200 \\
Breaking cooling (\%) & 50 & 3.17 & 0.0010 & 81.77 & 0.8232 \\
Defrosting (\%) & 54 & 9.21 & 0.0127 & 42.36 & 0.4157 \\
Cooking loss (\%) & 70 & 25.91 & 0.0110 & 26.88 & 0.3862 \\
Shear, kgf $^{3}$ & 46 & 4.40 & 0.0194 & 50.17 & 0.3549 \\
Palatability, points $^{4}$ & 59 & 6.64 & 0.0109 & 10.02 & 0.4296 \\
Succulence, points $^{4}$ & 56 & 6.44 & 0.0273 & 11.09 & 0.2233 \\
Conformations, points $^{1}$ & 50 & 10.28 & 0.0025 & 20.80 & 0.7266 \\
\hline
\end{tabular}

${ }^{*} \mathrm{~N}^{\circ}=$ number of observations; $\mathrm{R}^{2}=$ coefficient of determination; $\mathrm{CV}=$ coefficient of variation (\%); $\mathrm{P} \%$ = probability; 1 = scale measured in points 1 to $18 ; 2=$ scale measured in points 1 to $5 ; 3=$ kilograms force; $4=$ scale measured in points 1 to 9 . 
cooking are influenced by the degree of marbling; therefore, given that marbling is directly related to fat thickness, it would be expected that higher SFT would result in greater marbling, thus helping to ensure that muscle fibers are protected and leading to lower degrees of rupture and liquid loss.

\section{CONCLUSION}

We found that an SFT of $6.0 \mathrm{~mm}$ provided adequate $\mathrm{HCW}$ and $\mathrm{CCW}$ yields and produced carcasses with high amounts of edible meat. Thus, we concluded that the degree of finish has no effect on the organoleptic characteristics of the meat of steers finished in feedlots and slaughtered at 2 years of age.

\section{REFERENCES}

ARBOITTE, M.Z. et al. Meat quality of the longissimus dorsi muscle of Aberdeen Angus steers of small and medium frame score, slaughtered at the same carcass finishing stage. Acta Scientiarum, Animal Sciences, vol. 33, n. 2, p. 191-198, 2011. Available from: $\quad<$ http://dx.doi.org/10.4025/actascianimsci.v33i2.10746>. Accessed: Oct. 10,2016.

BERG, R.T.; BUTTERFIELD, R.M. New concepts of cattle growth. Sydney: Sydney University Press, 1976. 240 p.

CATTELAM, J. et al. Carcass Physical Composition and Meat Quality of Steers and Cull Cows of Different Genetic Groups Submitted to Different Feeding Frequency. Ciência Animal Brasileira, v. 10, n. 3, p. 764-775, Jul/Set 2009. Available from: $<$ http://189.126.110.61/cab/article/download/7086/7311.>. Accessed: Oct. 12,2016.

DONICHT, P.A.M.M. et al. Fat sources in diets for feedlotfinished steers - carcass and meat characteristics. Ciência Animal Brasileira, v. 12 n. 3, 2011. Available from: $<$ https://www.revistas. ufg.br/vet/article/view/14008/9679. . . Accessed: Oct. 12, 2016.

FERNANDES, A.R.M. et al. Carcass and meat characteristic of cattle receiving differents diets in feedlot. Arquivo Brasileiro de Medicina Veterinária e Zootecnia, v. 60, n. 1, p. 139147, 2008. Available from: $<$ http://dx.doi.org/10.1590/s010209352008000100020>. Accessed: Oct. 12, 2016.

FIORENTINI, G. et al. Qualitative characteristics of meat from confined crossbred heifers fed with lipid sources. Scientia Agricola, v. 69, n. 5, p. 336-344, 2012. Available from: $<$ http://dx.doi.org/10.1590/s0103-90162012000500008>. Accessed: Dec. 14, 2016.

GESUALDI, A.J. et al. Carcass traits of genetically improved Nellore and caracu bulls fed ad libitum or feed-restricted. Revista Brasileira de Zootecnia, v. 35, n. 1, p.131-138, 2006. Available from: $\quad<$ http://dx.doi.org/10.1590/s1516-35982006000100017>. Accessed: Dec. 02 , 2016.
GOMES, R.C. et al. Carcass quality of feedlot finished steers fed yeast, monensin, and the association of both additives. Arquivo Brasileiro de Medicina Veterinaria e Zootecnicia, v. 61, n. 3, p.648-654, 2009. Available from: <http://dx.doi.org/10.1590/ s0102-09352009000300018>. Accessed: Dec. 02, 2016.

GONZÁLEZ L.A. et al. Factors affecting body weight loss during commercial long haul transport of cattle in North America. Journal of Animal Science, 2012; 90(10):3630-3639. Available from: <http:// dx.doi.org/10.2527/jas.2011-4786>. Accessed: Oct. 12, 2016.

LAWRIE, R.A. Ciência da la carne. 6. ed. editora Artmed, 2005. 384 p. ISBN: 85-363-0459-6.

MAGGIONI, D. et al. Bermuda grass hay or sorghum silage with or without yeast addition on performance and carcass characteristics of crossbred young bulls finished in feedlot. Asian-Australasian Journal of Animal Sciences, Seoul, v. 22 n. 2, p.206-215, 2009. Available from: <http://doi.org/10.5713/ajas.2009.80224.>. Accessed: Dec. 05, 2016.

MENEZES, L.F.G. et al. Carcass and meat characteristics from young Devon steers finished in different feeding systems. Revista Brasileira de Zootecnia, v. 39, n. 3, p.667-676, 2010. Available from: <http://dx.doi.org/10.1590/s1516-35982010000300028>. Accessed: Oct. 12, 2016.

METZ, P.A.M. et al. Fatty acids profile in meat of steers from different ages and genetic groups finished in feedlot. Revista Brasileira de Zootecnia, v. 38, n. 3, p.523-531, 2009. Available from: $<$ http://dx.doi. org/10.1590/s1516-35982009000300018>. Accessed: Oct. 12, 2016.

NÜRNBERG, K. et al. Factors influencing fat composition in muscle and adipose tissue of farm animals. Livestock Production Science, v. 56, p.145-156, 1998. Available from: <http://dx.doi.org/10.1016/S0301-6226(98)00188-2>. Accessed: Sept. 24, 2016.

PRADO, I.N. et al. Meat quality of crossbred bulls fed with sorghum silage or sugar cane and slaughtered at two levels of fat thickness. Acta Scientiarum Technology, Maringá, v. 34, n. 3, p.337-344, 2012. Available from: <http://dx.doi.org/10.4025/ actascitechnol.v34i3.15121>. Accessed: Sept. 24, 2016.

PINHEIRO, R.M.K. et al. Influence of breed, gender condition, and anti-parasitic treatment on the measurements of in vivo rib eye area and fat thickness and on the carcass of beef cattle Arquivo Brasileiro de Medicina Veterinária e Zootecnia, v. 61, n. 3, p.676-681, 2009. Available from: <http://dx.doi.org/10.1590/ s0102-09352009000300022>. Accessed: Sept. 24, 2016.

ROTHER, E. T. Systematic literature review x narrative review. Acta, Paulista de Enfermagem, v. 20, n. 2, 2007.

SAS INSTITUTE. SAS/STAT. User's guide: statistics. Cary: SAS Institute, 2004.

SMITH, S.P. et al. Regulation of fat and fatty acid composition in beef cattle. Asian-Australasian Journal of Animal Science, Seoul, v. 22, n. 9, p.1225-1233, 2009. Available from: <http:// www.ajas.info/upload/pdf/22-162.pdf.>. Accessed: Oct. 12, 2016. 